\title{
Assessment of impact of stylus length on measurement accuracy for 5-axis coordinate measuring systems
}

\author{
Analiza wpływu długości trzpienia na dokładność pomiaru \\ 5-osiowym systemem współrzędnościowym
}

PIOTR GACSKA

ADAM GASKA

MACIEJ GRUZA

KSENIA OSTROWSKA JERZY SŁADEK*

Length of stylus used during measurements performed on CMMs is one of the important factors which affect their accuracy. Authors decided to investigate how this factor affects the measurement done in 5-axis mode when articulated probe head is used for adding 2 supplementary rotary movements during measurements. Described research utilize well-known methodology based on measurement of material standards. The impact of the stylus length on obtained results was estimated and conclusions were drawn.

KEYWORDS: articulating probe head, measurement accuracy

Długość trzpienia wykorzystywanego w trakcie pomiarów na współrzędnościowych maszynach pomiarowych należy do waźnych czynników oddziałujących na dokładność pomiaru. Autorzy postanowili sprawdzić, jaki wpływ ma na pomiary przeprowadzane w trybie 5-osiowym, w którym specjalna głowica obrotowo-uchylna pozwala na wykorzystanie 2 ruchów obrotowych w trakcie pomiaru. Badania oparto na znanej metodyce obejmującej pomiar obiektów wzorcowych. Oszacowano wpływ długości trzpienia na dokładność tego rodzaju pomiarów oraz przedstawiono wnioski.

SŁOWA KLUCZOWE: głowice obrotowo-uchylne, dokładność pomiaru

The development of manufacturing technology forces the progress in coordinate metrology. New measuring systems are constantly constructed while proven solutions are still tested and improved. One of the main problems of coordinate metrology is how to accelerate the measurement process without losing its high accuracy. Tactile methods are developed to meet above mentioned requirement, among them: scanning methods and new generation of articulated probe heads, which enable measurements in the so-called 5-axis mode. In this mode, 2 additional rotations of probe head around the mutually perpendicular axes are added to standard moves of CMM. It allows, especially in case of circular features inspection, to perform measurement with limited influence of CMM kinematics. Such approach not only decreases measurement duration but also reduces negative effects connected with the acceleration of CMM parts. An example of such solution is Renishaw $\mathrm{PH} 20$ probe. It has 2 revolute joints, first one rotates around horizontal, so-called $A$ axis in range between $-115^{\circ}$ and $115^{\circ}$, while second one rotates around vertical $B$ axis and its working range is unlimited.

The factors affecting the operation of the probe heads used in 3-axis mode and their impact on measurement accuracy are known and have been described in many literature positions $[1-5,7,8]$. One of them is length of the

\footnotetext{
* Mgr inż. Piotr Gąska (piotr.gaska@pk.edu.pl), dr inż. Adam Gąska (agaska@mech.pk.edu.pl), mgr inż. Maciej Gruza (gruzam@interia.pl), dr inż. Ksenia Ostrowska (kostrowska@mech.pk.edu.pl), prof. dr hab. inż. Jerzy Sładek (sladek@mech.pk.edu.pl) - Laboratorium Metrologii Współrzędnościowej Politechniki Krakowskiej
}

\author{
DOI: https://doi.org/10.17814/mechanik.2017.11.170
}

stylus which was used during measurement. The increase in stylus length may cause greater probe deflection during contact and enhance drop under gravity in case of a probe horizontal orientation. The authors decided to test how this factor affects the measurements conducted in a 5-axis mode. The well-known methodology of probe head testing, based on multiple measurement of material standards was utilized during research.

\section{Experiment and results}

The experiments described in this paper were performed in order to estimate the impact of the stylus length on the accuracy of measurement done in 5-axis mode. The experiment involved multiple measurements of ring gauges in repeatable conditions. All measurements described in this paper were performed using Zeiss WMM 850S machine located in Laboratory of Coordinate Metrology at Cracow University of Technology. It is a machine with moving bridge, with measuring volume of about $800112001700 \mathrm{~mm}$. The temperature during measurements was in the range of $19.7^{\circ} \mathrm{C} \pm 0.4^{\circ} \mathrm{C}$. The measurements were performed using Renishaw $\mathrm{PH} 20$ probe head with TP20 STD Force probe.

The first stage of experiments involved measurements of ring gauge of $20 \mathrm{~mm}$ diameter, which was installed in the machine volume in such a way that its axis was parallel to $z$-axis of machine (fig. 1). The form deviation of chosen ring is less than $0.2 \times P_{\mathrm{FTU}}$ defined according to [6]. The ring was calibrated in Laboratory of Coordinate Metrology with Leitz PMM machine. According to [3] the physical standards as rings and spheres can be used in order to find the probe head characteristic. Assuming that standard object form error is negligible considering probe head accuracy, and that the ring diameter is small enough to minimize the influence of machine kinematics on measurement results, the errors obtained during measurements can be attributed mostly to probe head. Errors characteristics obtained in such a manner are utilized to compare the probe heads of different types. They can be also useful for checking the influence of different factors on probe head operation.

The manufacturer declares that for this type of TP20 probe used, stylus length should be within the range from $10 \mathrm{~mm}$ to $50 \mathrm{~mm}$. The 3 lengths of stylus were chosen for tests: $12 \mathrm{~mm}, 32 \mathrm{~mm}$ and $42 \mathrm{~mm}$. The same tip of $4 \mathrm{~mm}$ diameter was used in all cases, and the stylus length was modified using appropriate extensions. Ring was measured in 64 evenly distributed measuring points located at circular intersection of ring in the middle of its height. The measured points distribution was the same as during calibration. The ring diameter and form deviation were tested 10 times for each stylus length, then the mean deviations were calculated. 


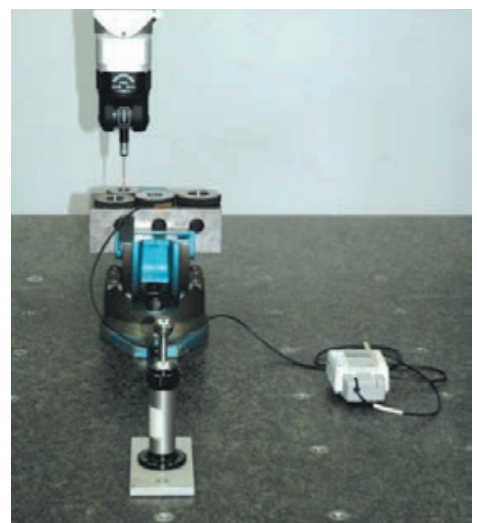

Fig. 1. The measurement set-up. Horizontal arrangement of reference rings

The results of diameter and form measurements are presented in fig. 2 and fig. 3. Obtained probe error characteristic can be seen on fig. 4 .

However, in this configuration of the ring, $\mathrm{PH} 20$ probe head measures the circular features in such a way that,
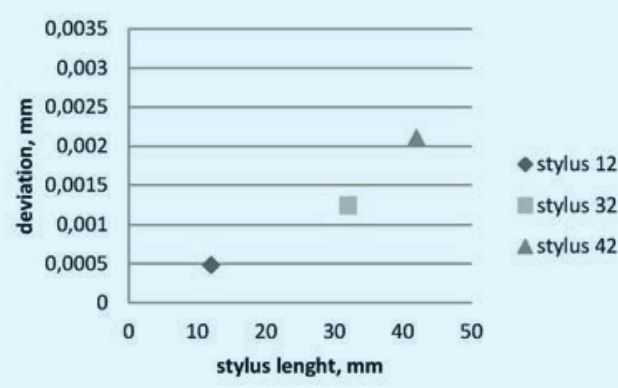

Fig. 2. The mean diameter deviation in relation to stylus length in $\mathrm{mm}$ Ring gauge ( $20 \mathrm{~mm}$ diameter) in horizontal position

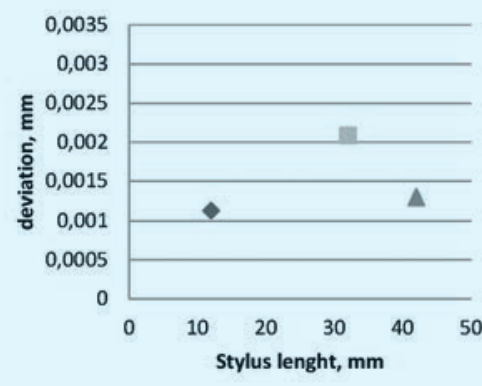

- stylus 12

anstylus 32

$\triangle$ stylus 42

Fig. 3. The mean form deviation in relation to stylus length in $\mathrm{mm}$. Ring gauge (20 $\mathrm{mm}$ diameter) in horizontal position

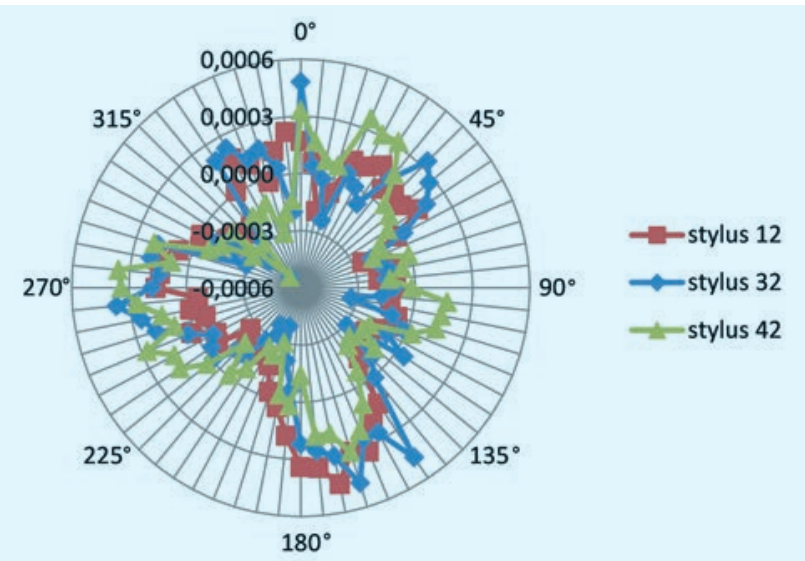

Fig. 4. Probe head error characteristic obtained for different stylus lengths in $\mathrm{mm}$. Ring gauge (20 mm diameter) in horizontal position the tip is deflected only in one direction. Firstly probe rotates around the $B$ axis, then only the rotations around $A$ axis are used during measurement. Therefore authors decided to check probe head functioning in another ring arrangement. In second stage of experiment the ring was installed in such a manner that the angle between ring axis and $z$-axis of machine was about $45^{\circ}$.

In this configuration the points measurements have to be done using both ( $A$ and $B$ ) probe rotations. The measurement procedure was repeated and obtained results are presented in fig. 5-7.

The increase in length of the stylus, in case of measurements of the same ring, results in the change of the $A$ angle range that is used during measurement. Thus, for each extended stylus length, authors decided to measure ring gauge characterised by such dimension that $A$ angle changes would be as close as possible to those used in case of $20 \mathrm{~mm}$ ring measurement with $12 \mathrm{~mm}$ stylus length. The following rings were used: for $32 \mathrm{~mm}$ stylus length, ring of $25 \mathrm{~mm}$ diameter, for $42 \mathrm{~mm}$ stylus

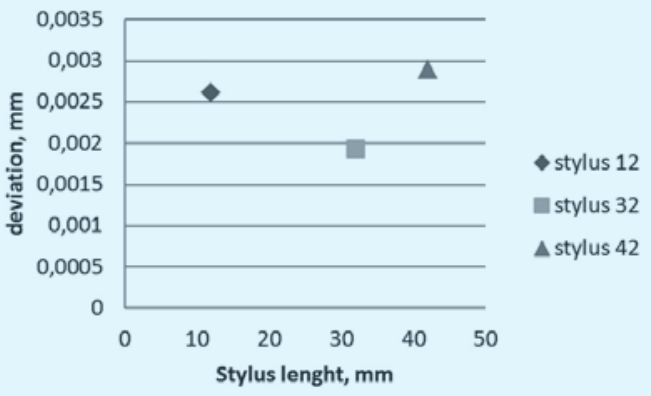

Fig. 5. The mean diameter deviation in relation to stylus length in $\mathrm{mm}$. Ring gauge (20 $\mathrm{mm}$ diameter) in oblique position

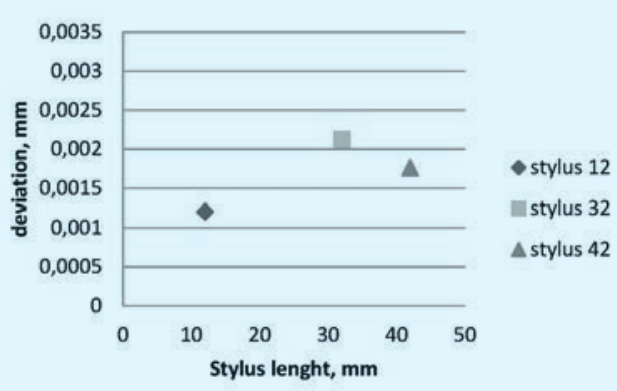

Fig. 6. The mean form deviation in relation to stylus length in $\mathrm{mm}$. Ring gauge (20 $\mathrm{mm}$ diameter) in oblique position

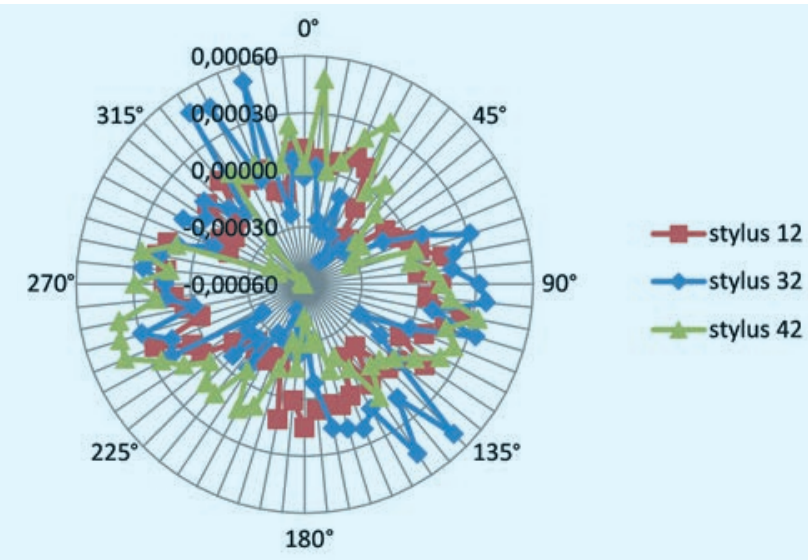

Fig. 7. Probe head error characteristic obtained for different stylus lengths in $\mathrm{mm}$. Ring gauge (20 $\mathrm{mm}$ diameter) in oblique position 
length, ring of $28 \mathrm{~mm}$ diameter. All rings were calibrated on Leitz PMM machine before experiments. By measuring the ring at the same points as in the calibration process, the impact of form deviation of the reference rings was minimized (the deviations at all measured points of each ring were compensated and thus the rings should be treated as having almost null form deviation). The measuring procedure was the same as previously described. The results for form errors measurements are presented in fig. 8-11.

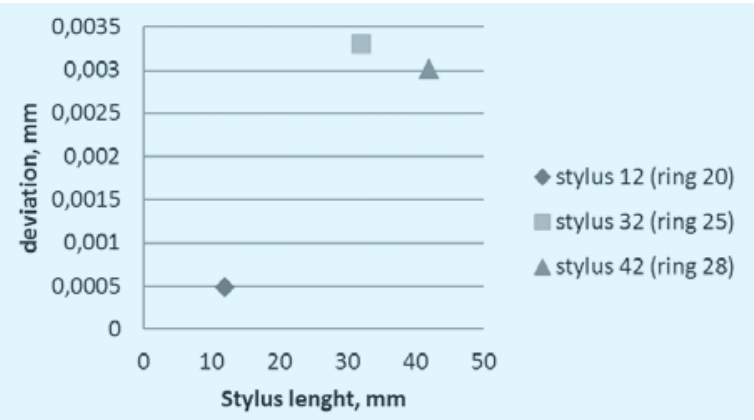

Fig. 8. The mean diameter deviation in relation to stylus length in $\mathrm{mm}$ Measurements performed for different rings in horizontal position

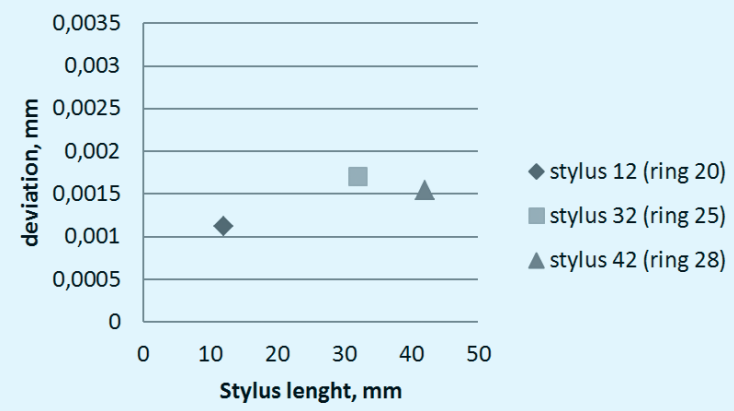

Fig. 9. The mean form deviation in relation to stylus length in $\mathrm{mm}$. Measurements performed for different rings in horizontal position

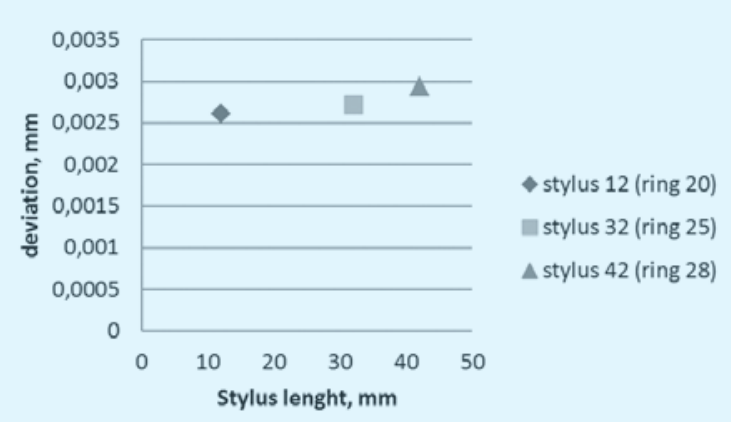

Fig. 10. The mean diameter deviation in relation to stylus length in $\mathrm{mm}$. Measurements performed for different rings in oblique position

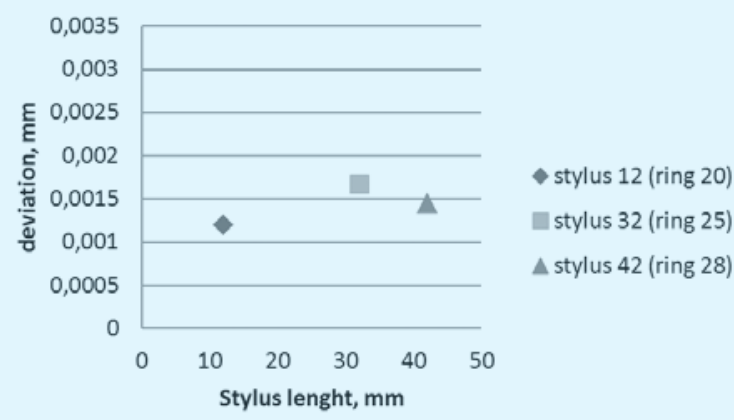

Fig. 11. The mean form deviation in relation to stylus length in $\mathrm{mm}$ Measurements performed for different rings in oblique position

\section{Conclusions}

In order to determine the impact of stylus length on measurement result the analysis of variance (for $\alpha=0,05$ ) was used. The significant influence was observed in all examined cases, however the greatest impact was observed for diameter measurements in the horizontal position of the ring.

In this setting of the ring the deviation obtained in diameter measurements increases as the stylus length is extending. The relationship between stylus length and diameter deviation is not so clear when rings are mounted at a different angle to the $B$ axis of the head. Then, the differences in results are smaller than for measurements done in horizontal position (less than $1 \mu \mathrm{m}$ for oblique position comparing to almost $2 \mu \mathrm{m}$ for horizontal position).

The results obtained during measurements of $20 \mathrm{~mm}$ ring and other rings, regarding both diameter and form deviations, were similar, so it can be concluded that changes in a working range of $A$ angle does not have a noticeable impact on the results (at least in differences not exceeding 5 degrees).

Moreover it can be observed that changes in the length of the stylus does not significantly affect the measurements of the form deviation.

The error characteristic obtained for the horizontal position of the ring is unexpected. Although the distinctive triangular characteristic is typical for TP 20 probes, during first stage of experiment all points were measured with the same direction of deflection of the probe (in this case the TP20 characteristics should not influence the characteristics of probe head working in 5-axis mode). It seems that such characteristic is probably caused by the functioning, construction or calibration process of $\mathrm{PH} 20$ head. The characteristics obtained in oblique setting of ring have more than 3 extremes, which may be caused by accumulation of errors of TP20 probe (during measurements in oblique setting TP20 deflects in different directions), and errors of the $\mathrm{PH} 20$ head.

Presented experiments have given interesting results. Research will be continued in order to obtain a more exact conclusions. Certainly the measurements should be performed for more reference ring settings to determine whether the results retain their character in whole working range of the $\mathrm{PH} 20$ head or are unique for certain $A$ and $B$ angles.

Reported research was realized as part of a project financed by the National Science Centre, Poland no.: 2015/17/D/ST8/01280.

\section{LITERATURA}

1. Hocken R.J., Pereira P.H. „Coordinate Measuring Machines and Systems". CRC Press, 2012.

2. Cauchick-Miguel P.A., King T.G. "Factors which influence CMM touch trigger probe performance". International Journal of Machine Tools and Manufacture. 38, 4 (1998): pp 363-374.

3. Sładek J. "Coordinate Metrology Accuracy of Systems and Measurements". Springer, 2016.

4. Weckenmann A., Estler T., Peggs G., Mcmurtry D. "Probing systems in dimensional metrology". CIRP Annals-Manufacturing Technology. 53 , 2 (2004): pp. 657-684.

5. Woźniak A. "Dokładność stykowych głowic pomiarowych maszyn współrzędnościowych". Warszawa: Oficyna Wydawnicza Politechniki Warszawskiej, 2010.

6. ISO 10360-5:2010: Geometrical product specifications (GPS) - Acceptance and reverification tests for coordinate measuring machines (CMM) - Part 5: CMMs using single and multiple stylus contacting probing systems. $2^{\text {nd }}$ ed. 2010.

7. Ratajczyk E., Woźniak A. "Współrzędnościowe systemy pomiarowe”. Warszawa: Oficyna Wydawnicza Politechniki Warszawskiej, 2016.

8. Wozniak A., Dobosz M. "Metrological feasibilities of CMM touch-trigger probes". Part II: "3D theoretical model of probe pretravel". Measurement. 34, 4 (2003): pp. 287-299. 